\title{
The Pervasive Silence of Enslaved Woman and the Dichotomy of White Woman as Property and Proprietor \\ Chantal McFarlane
}

Chantal Noelene McFarlane is an undergraduate student at the University of Toronto majoring in Caribbean Studies and English. Her present area of focus includes 18th century British literature and the racial underpinnings of such work in their representation of the Caribbean. She hopes that at some point her fascination with the history of the Caribbean and her love for literature will allow her to author her own understanding of this indefinable archipelago.

Valerie Martin's Property is a historical fiction that gives a representation of the white female consciousness during the time of Atlantic slavery. The theme of gender is blatantly brought out in this text; it acts as the crux for the novel. Gender during the time of slavery should not be conflated with a contemporary understanding of it. During this era black women were virtually viewed as unsexed, by whites, except when it came to pleasing white masters or overseers sexually. This paper will look extensively at the relationship that exist between the main protagonist Manon Guadet and Sarah, her house slave, essentially dissecting the black-white dynamics as portrayed by Valerie Martin. Its main tenet will be looking at what Sabine Broeck calls the 'ungenedered-gendered' response between black and white women during slavery. It will use Lucille Mathurin Mair's analysis of women during slavery to support the claim that the vast difference between, how the white female body and black female body are received is one that is based on the institution of slavery. The main criticism of the text will revolve around what I perceive to be the blatant silencing of the black female and how Manon is read as property and proprietor.

Valerie Martin, in Property, makes known the life of Manon Gaduet; in Louisiana during the height of plantation slavery in America. Manon, the main protagonist, fulfills her role dutifully as wife while having an aloof almost voyeuristic stance within slavery. She is seen as orbiting the edge of slavery never a full participant as is iterated through her sexual encounters with her husband. Manon states emphatically "I offered neither encouragement nor resistance; I was there and not there at the same time". ${ }^{1}$ This act of being on the

1 Valerie Martin, Property (New York: Vintage, 2003), 56. 
periphery but at the same time embodying the centre is one that becomes analogous to white women's conceptualization of slavery. They were at once there and not there, however, this dichotomous spatial characterization becomes problematic as the white woman, in Manon's regards, loses all form of agency during this period which was not necessarily so. Lucille Mathurin Mair's Historical Study of Women, concentrates on women in Jamaica during slavery. Her findings can be used to characterize the lived reality of women in America at the time. Property is representative of most of Mair's claims. Mair states that white women existed at two levels that of the "delicate beings, requiring masculine protection and as good creatures ... Then, there was as well the level of their own actual existence, which often fell short of the idealized perfection." 2 The positioning of the white woman as these delicate beings has made them property in the sense, however on the level of their own existence they are also proprietor. They traverse the delicate balance of owning and being 'owned'.

The title of the novel, Property, speaks unequivocally to the ownership of slaves on a very literal level as well as more subtle to the ownership of Manon by her husband. The various kind of owning based on an outright ownership and that of the implicitly owned is a theme that one should be very critical of in the novel. The subject of property and gender is one, as Lucille Mathurin Mair states, where the husband "took instant and complete possession of all" the wife's "personal property" 3 and to an extent herself. The immediate 'possession' (possession here does not imply complete ownership) that is taken of the white woman's person should not be conflated with the fact that it was the very being of the enslaved that was made property, the institution of Atlantic slavery stretched to consume every morsel of the enslaved Africans' identity. The conflation of the idea of what it means to be property based on the novel is reminiscent of Elizabeth Fox-Genovese's Within the Plantation Household. Genovese viewed the 'kinship' between white and black women in plantation housing as one that was mutually intertwined "where they shared a world of physical and emotional intimacy." 4 The intimacy that is characterized by Genovese is one that is mutual

\footnotetext{
2 Lucille Mathurin Mair, A Historical Study of Women in Jamaica 1655-

1844,(Kingston: UWI Press, 2006), 117.

3 Mair, Historical Study 151

4 Elizabeth Fox-Genovese, Within the Plantation Household, (London: The University of South Carolina Press), 101.
} 
however in this 'mutuality' the black woman has to be complicit whether she wants to or not. Thus the concept of mutuality changes meaning as enslaved woman is openly compromised. The mutuality of their interactions has to be weighed based on the fact that the enslaved woman always played a secondary role, as in Property where it is clearly laid out that Sarah is the slave and Manon is married property which gives her quite a significant leverage.

The stringent conditions between black female and white female relation during the time of slavery is blatantly represented in Valerie Martin's work. It elucidates the very concept of "property" as evidenced by its title and how this notion transcends both black and white experiences to make it an all encompassing one. This however gives rise to the criticism that the idea of property is one that is suspect to gradation. That is, in respects to understanding that both Sarah and Manon are constructed as property, Sarah is more 'owned' than the latter. The novel opens with an epigraph from an A.B.C. of Halifax dated 1832. Martin only incorporated a snippet of the entire thing which continues: "Property which is considered the most valuable by the owners of it, is a nice thing; and for the right thereto, to be called in question by an unphilosophical set of political mountebanks, under the influence of supernatural agency or deceit, is insufferable." 5 The need to keep one's property beyond everything else is shown in Property which takes away from the mutuality of kinship between black women and white women, as it is Manon who has Sarah hunted to bring her back to slavery. The epigraph in full highlights this, however the snippet that Martin gives fails to incorporate the fact that the very idea of property is very contentious as shown above.

What is most problematic in Property is that Manon will be read as property as well as Sarah, the distinction between the two needs to be made explicit which the novel quintessentially fails to do. This coupled with Sarah's evident silence becomes more problematic. The pervasive silence that is used to embody Sarah's character is one which shows a distinction between her and Manon and reinscribes the historic muteness of the black female as performed by historians.

5 Herbert Aptheker, American Negro Slavery, (Columbia: Columbia Uni. Press, 1963), 302 
Property received the Orange prize for literature in 2003; a statement by Ahdaf Souief is that the novel "looks at the relationships of power and ownership among people living in a system which is manifestly evil" 6 this characterization of the novel is one that is in its understanding almost a universal truth. Souief fails to acknowledge that the lens through which the relationship is being looked at is overtly one sided. This consideration is essential in analyzing the novel.

It is clear that Martin constructs the character of Manon to be an almost shrewd unfeeling woman living under the shadow of her husband whose joy for life has been sapped by the sheer understanding of slavery. This understanding is contentious as Manon partakes in the "manifestly evil" system with hardly a regard for her slaves, her joy for life is sapped not by the realities of slavery but by the fact that she does not love or respect her husband in any light. The voyeuristic stance that she takes does not mean that she is opposed to the happenings. The opening of the novel has her peering through her proverbial spy glass and watching the perverted homoerotic violence that is being perpetrated against the young boys who are enslaved, her statement "I couldn't watch anymore" does take away from the fact that such violence was carried out constantly and her role is of a participant especially in her treatment towards Sarah.

Sabine Broeck cast a critical eye on the relationship that exists between Manon and Sarah. Broeck uses the poignant scene in the text where Manon sucks the milk from Sarah's breast. She states "The slave literally, in this scene, becomes an un-gendered breast to fulfill the white woman's dreams both of power, and of the physical comfort of body nurturance - which seems to be an ingenious textual signification on the hundreds of scenes of black mammies feeding white babies in American cultural memory, nursing them into masterhood"7. This understanding that Sarah is suckling Manon into masterhood is pivotal to the understanding of the text. As it is directly after this that Manon becomes master, losing her husband and being a widow. Broeck further elaborates that "The gendered subjectification of the white woman - her freedom as an agent of her own desire - is literally sucked from the black woman's body, contingent on the de- subjectification, and thus the de-gendering of

\footnotetext{
6 Valerie Martin, Property (New York: Vintage,2003),

7 Sabine Broeck, "Property: White Gender and Slavery," Gender Forum an Internet Journal for Gender Studies 14 (2006)
} 
the enslaved human being who has become her serviceable flesh, as it were." 8 The changing of Manon's own agency is prefigured in this. Through this act the novel unfolds where Manon is no longer property but proprietor. Manon projects her future through this act, "I could see my husband in his office, lifting his head from his books with an uncomfortable suspicion that something important was not adding up. This vision made me smile."9 Manon's vision is complete at the death of her husband "He was dead ... I smiled wanly at my altered reflection"10, her altered reflection shows that she no longer answers to the quintessential gendered norms of the antebellum of the south but has now embodied the true position of white master.

Fox-Genovese states that "Women were bound to each other in the household, not in sisterhood, but by their specific and different relations to their master." 11 This bond is reflected throughout Property. Sarah and Manon are indeed bounded; however the links that keep them to the master, who has remained nameless throughout the entire text except for his initials after his death, is not the same. Their bond is also cut with Manon's "altered reflection."

Sarah's petit marronage is nullified in this text as it becomes hinged on the loss of Manon. Valerie Martin's work is groundbreaking as it taps into the white female psyche at the time without the wanton need of glorification or the need to position the white woman as all innocent. What becomes detrimental to the development of the novel is the pervasive silence that is Sarah's existence. Valerie Martin is indeed positioning this novel as a break from the abolitionist female spectra at the same time the quietening of Sarah fully takes away from her female agency; it undermines the enslaved African females' ability to construct any form of resistance. Notably throughout this narrative is the reoccurrence of Walter, Sarah's son. Walter stands in as the clear hybridization of the New World of new peoples. He is virtually represented as a "creature" that is only capable of loud "babbling" noises. The fact that Sarah does not speak and Walter is the only person who does gives the idea

\footnotetext{
8 Broeck

9 Valerie Martin, Property (New York: Vintage,2003),76

10 Martin 134

11 Elizabeth Fox-Genovese, Within the Plantation Household, (London: The University of South Carolina Press),
} 
that the only form of communication capable from the enslaved is incoherency.

The most readily identifiable symbol in Property is Manon's "spyglass" this spyglass represents several things at once; the fact that as readers we will always be distant from the actual event based on the fact that it is in the past and the relationship that Manon tries to have with slavery. Valerie Martin establishes that perspectives are relative as is evidence by the shattering of the glass. "The spyglass was dismantled and lay in pieces on the carpet" (134, Martin) the dismantling of the spyglass represents the shattering of Manon's distance from the actuality of slavery, her coming into being master of her slaves and her removal from the role of property. According to Broeck Manon's “need" for Sarah goes beyond that of the need to be served and assert herself as a propertied female and more of a way to celebrate her "trans-aggressive sexual freedom" which could only be previously explored through her voyeuristic spyglass.

I am not suggesting that this text is polemical however its very structure borrows from that of the construction of history wherein only the voice of the privileged is heard. The author's need to enlist the unpitying stance of the protagonist is commendable however the tension that arises from Sarah's silence is left to question. The only time that she speaks is at the end of the novel, which signifies the fact that her thoughts need not be elaborated on as it is not profound enough to be transcribed. Property subtly acknowledges historic understandings of being owned and the varying degrees of being property. 
CARIBBEAN QUILT | 2013

\section{Works Cited}

Aptheker, Herbert. American Negro Slavery. Columbia: Columbia Uni. Press. (1963)

Broeck, Sabine. "Property: White Gender and Slavery" in Gender Forum: An Internet Journal for Gender Studies 14. (2006). (Web)

Bynum, Victoria. Unruly Women: The Politics of Social and Sexual Control in the Old South.

London: The University of North Carolina Press (1992).

Fox-Genovese, Elizabeth. Within the Plantation Household: Black and White Women of the Old South. London: The University of North Carolina Press (1988)

Hawks, Joanne V. and Sheila L. Skemp. Sex, Race, and the Role of Women in the South Jackson: University Press of Mississippi (1983)

Martin, Valerie. Property. New York: Vintage Books (2003) 